\title{
Corporate Social Responsibility of Chinese SMEs: Implementation and Challenges
}

\author{
Khaled Mohammed Alqahtani*, Pingping Song**
}

The research scope of corporate social responsibility (CSR) has been growing increasingly popular in emerging economies, whereas the knowledge relating to CSR in the case of small and medium enterprises (SMEs) is still limited. This study starts with the definition of CSR and an explanation regarding the relation between CSR and marketing. Descriptions of CSR in China and Chinese SMEs are presented as well. This research aims to identify the situation of CSR as adopted by Chinese SMEs in the current economic environment as well as to analyze the challenges of their implementation. To achieve these research objectives, twenty different SMEs in Guangdong Province were investigated through in-depth semi-structured interviews. This study shows that CSR is still in an infant stage for the majority of Chinese SMEs due to the incomplete legal system, weak CSR awareness, and deficient financial resources. Moreover, several appropriate suggestions for policy makers and the enterprises themselves are recommended in order to improve the future CSR performance of Chinese SMEs.

Keywords: SMEs, China, corporate social responsibility, practices and outcomes, challenges and recommendations.

Submitted: 07.12.2015 | Accepted: 27.04.2016

\section{Społeczna odpowiedzialność chińskich MŚP: wdrożenie, realizacja i wyzwania}

Badania z zakresu spotecznej odpowiedzialności biznesu (CSR) sa coraz bardziej popularne $w$ gospodarkach rozwijajacych się, jednak wiedza $w$ zakresie CSR $w$ matych $i$ średnich przedsiębiorstwach (MŚP) jest wciaż ograniczona. To studium rozpoczyna się od definicji CSR oraz wyjaśnienia powiązań pomiędzy CSR a marketingiem. Przedmiotem opracowania jest również opis CSR w Chinach i chińskich przedsiębiorstwach należacych do sektora MŚP. Przedstawione badanie ma na celu określenie aktualnej sytuacji CSR przyjętej przez chińskich $M S ́ P$ w obecnej sytuacji gospodarczej, a także analize problemów zwiazanych z ich realizacja. $W$ trakcie analizy szczegótowo przebadano dwadzieścia różnych MŚP w prowincji Guangdong za pomoca pót-ustrukturyzowanego wywiadu z powyższymi przedsiębiorstwami. Wyniki wskazuja, że CSR jest wciąz na wczesnym etapie rozwoju w większości chińskich MŚP, czego przyczyna sa luki w systemie prawnym, mała świadomość CSR oraz ograniczone środki finansowe. Ponadto, w pracy przedstawiono kilka propozycji dla decydentów oraz przedsiębiorstw, które zalecane sq w celu poprawy przyszłych wyników CSR chińskich MŚP.

* Khaled Mohammed Alqahtani - Assistant Professor at the Business School Shaqra University. Mailing address: Business School Shaqra University, P.O. Box 88058, 11662 Riyadh, Kingdom of Saudi Arabia; Faculty of Management University of Warsaw, 1/3 Szturmowa St., 02-678 Warsaw; e-mail: dr_khaled@126.com.

** Pingping Song - Ph.D. Candidate at the Faculty of Management University of Warsaw.

Mailing address: Faculty of Management University of Warsaw, 1/3 Szturmowa St., 02-678 Warsaw; e-mail: psong@wz.uw.edu.pl. Ministry of Science
and Higher Education Republic of Poland
The creation of the English-language version of these publications is financed in the framework of contract No. 768/P-DUN/2016 by the Ministry of Science and Higher Education committed to activities aimed at the promotion of education. 
Słowa kluczowe: MŚP, Chiny, badania społecznej odpowiedzialności biznesu (Corporate Social Responsibility), ćwiczenia i ich rezultaty, wyzwania i zalecenia.

Nadesłany: 07.12.2015 | Zaakceptowany do druku: 27.04.2016

JEL: M00, M100, M140, M380

\section{Introduction}

Together with the rapid process of globalization, interest in corporate social responsibility has shown an ascendant tendency over the past three decades from developed economies all the way to emerging countries (Mankelow, 2008). A part of the largest developing country and the second largest economy in the world (Whipp and Anderlini, 2010), a growing number of enterprises in China have been conducting their business more responsibly and ethically. This not only decreases the information gap between an enterprise and its stakeholders by bridging a communication channel, but also increases the value of an enterprise by managing its public reputation and image (Orlitzky et al., 2003; Li et al., 2013). However, the adoption of CSR has been mostly restricted to large enterprises instead of SMEs. This can be attributed to the much greater pressures and more requirements relating to CSR facing large companies (European Commission, 2001; Liu and Fong, 2010).

On the other hand, the contribution of any single SME is negligible compared with the multinational companies (MNCs). However, the cumulative contribution of all SMEs is considerable. In emerging economies, SMEs account for approximately ninety percent of all firms and are responsible for more than half of overall employment and total GDP on average (Luetkenhorst, 2003; Liu and Fong, 2010). For example, the approximately eight million Chinese SMEs of the late 1990s increased to around 48.82 million in 2012. This represents more than $98 \%$ overall of firms with over a $60 \%$ contribution to national GDP growth in 2012 (Li, 2012). Therefore, as the most important participant of economic development, the collective involvements of CSR from all Chinese SMEs will create substantial benefits and exert significant impacts on a range of stakeholders.

Moreover, many MNCs come from CSR-oriented SMEs. For instance, some Chinese MNCs such as Lenovo and Haier started as small businesses that always actively committed to establish charity funds, rebuild communities, promote basic education, etc. (Liu and Fong, 2010). Ethical and responsible behavior is not only beneficial to society and the country as a whole, but also to the enterprise itself.

Owing to the increasingly vital role of SMEs in China, this study attempts to evaluate the CSR of Chinese SMEs and also identify the internal constraints and external challenges of its implementation. There are three key questions that need to be addressed:

1) What is the corporate social responsibility adopted by Chinese SMEs? To better understand the study context, it is important to analyze what CSR is for Chinese SMEs in the current business environment.

2) What are the motivations and reasons behind CSR in the case of Chinese SMEs and how successful is its implementation? To investigate the CSR of Chinese SMEs, twenty different SMEs were randomly selected in Guangzhou City, Shenzhen City, and Zhongshan City, which are three large cities of Guangdong Province. The motivations, practices, and outcomes of CSR implementation are discussed on the basis of successful semi-structured interviews with experienced managers.

3) What are the barriers to CSR implementation and how can CSR capability be strengthened? The internal constraints and external challenges of CSR as adopted by Chinese SMEs have been identified in accordance with the research findings. Several proper recommendations to solve related problems and overcome difficulties are provided as well.

\section{Literature Review}

\subsection{The Explanation of CSR in Marketing Literature}

CSR puts particular attention on the ethical, social, and environmental impli- 
cations of doing business (McWilliams et al., 2006; Xun, 2013). Marketing organizations are expected to undertake economic responsibilities as well as legal, ethical, environmental, and social responsibilities (Whetten et al., 2002; Kolk et al., 2010; Carroll, 1999). In other words, enterprises are not only sellers of their products, but also have inherent responsibilities, including being more responsible for their behavior and more responsive in dealing with social concerns.

Table 1 summarizes a large number of academic studies regarding CSR that can be found in the marketing field. Many researches specifically linking CSR to consumer behavior, corporate image, and job satisfaction have been explored by previous scholars. For example, the findings of many studies reveal that the well-done CSR initiatives could bolster the loyalty of consumers (Saunders, 2006; Raman et al., 2012; Pakseresht, 2010). According to Nik Ramli and Nor Irwani (2013), the adoption of CSR is helpful in igniting consumer identification with a particular enterprise. This is also conducive to the improvement of corporate image. Therefore, CSR is increasingly taken into account by more and more enterprises as a means of keeping and increasing customers. In addition, the policies of CSR can create a pleasant workplace. For instance, studies by Korschun et al. (2014) and Lee et al. (2011) show that the higher the implementation of CSR, the greater the job satisfaction of employees. Overall, an increasing number of firms are turning to CSR as the ultimate marketing tool to enhance their $\mathrm{m}$ arketing competitiveness.

\subsection{A Description of CSR in China}

Prior research into CSR mainly concentrated on large companies in developed countries, whereas the attention on the CSR of Chinese SMEs has been very limited so far. The concept of CSR started to be known in China through foreign investors at the end of 1990s. They required Chinese enterprises to attach great importance to guarantee employee equity, environmentally friendly production, and high quality products. Therefore, the relationship between commercial behavior (e.g., profit maximization) and corporate morality (e.g., social responsibility) was introduced to Chinese firms for the first time (Yin and Zhang, 2012; Zu and Song, 2009). However, CSR was not widely accepted by most companies when initially introduced into China, especially in the case of SMEs. This was because of allegations that CSR was a part of a "foreign scheme to price China out of the cheap labor market" or its simply being regarded as international interference. Chinese firms asserted that CSR originated from outside of China and was mainly driven by the Western antisweatshop campaigns (Kolk et al., 2010; Chan, 2005). For example, in 1999, there was only one enterprise releasing an annual report on CSR in China (Yin and Zhang,

Table 1. The Literature of CSR in Marketing Field

\begin{tabular}{|l|l|}
\hline \multicolumn{1}{|c|}{ Author(s) } & \multicolumn{1}{c|}{ Description } \\
\hline $\begin{array}{l}\text { Andresen (1994) } \\
\text { Daub and Ergenzinger (2005) }\end{array}$ & CSR in in the area of social marketing \\
\hline $\begin{array}{l}\text { Polonsky and Wood (2001) } \\
\text { Gupta and Pirsch (2006) } \\
\text { Chattananon et al. (2008) }\end{array}$ & CSR in in the area of cause-related marketing \\
\hline $\begin{array}{l}\text { Maignan and Mcalister (2003) } \\
\text { Oberseder et al. (2011) }\end{array}$ & CSR in in the area of socially responsible buying \\
\hline $\begin{array}{l}\text { Dolan (2002) } \\
\text { Vaaland et al. (2008) } \\
\text { Fedrigo and Hontelez (2010) }\end{array}$ & CSR in in the area of sustainable consumption \\
\hline
\end{tabular}

Source: Adapted from Maignan and Ferrell (2004); Nik Ramli et al. (2013).

Wydział Zarządzania UW ～DOI 10.7172/1733-9758.2016.20.5 
2012). Since accession to the World Trade Organization (WTO) in 2001 as well as the vigorous promotion of a harmonious society pursuing green GDP in 2005, more and more people have paid close attention to environmental and social problems, especially severe environment pollution, weak employee rights, and food safety hazards (Wang and Juslin, 2011). Meanwhile, in recent years, an increasing number of enterprises have put more emphasis on CSR, including SMEs in China (Xun, 2013). For example, the total number of Chinese firms publishing CSR reports increased to 703 in 2010 (Yin and Zhang, 2012).

Welford (2005) points out the development of CSR as being associated with the economic growth of various countries. In general, Chinese companies trail behind their Western counterparts in terms of CSR reporting (Noronha et al., 2013). According to an investigation on CSR adoption by Chinese enterprises conducted in March of 2014, CSR disclosure levels by Chinese enterprises were very low, in particular SMEs. Only $11 \%$ of Chinese companies were regarded as leaders in CSR reporting, approximately $19 \%$ were viewed as followers, around $21 \%$ were classified as beginners, and nearly $50 \%$ were grouped as observers (Chen et al., 2015). Moreover, CSR reports are usually disclosed according to localized issues and cultural traditions at a country level. For instance, there is less emphasis on bribery, employee development, and vocational education in CSR reports from Chinese firms, where there is more commitment to protecting human rights and guaranteeing the freedom of labor associations in European and North American companies (Welford, 2005).

As another example, it was reported that SMEs in China discharged over $60 \%$ of total emissions of industrial pollutants in 2013. However, $92.31 \%$ of Chinese SMEs invested less than ten percent of their sales revenue in environmental protection, including $78.37 \%$ of Chinese SMEs that invested less than five percent and $31.73 \%$ investing less than one percent. This is obviously inadequate for exerting any significant effect on their financial performance (China Council for International Cooperation on Environment and Sustainable Development, 2013). Generally speaking, China is not developing in a sustainable and efficient way. Some evidence shows that the rate of energy utilization in China is $33 \%$, which is $10 \%$ less than the standard achieved by developed countries. The rate of industrial water recycling is $55 \%$, which is $25 \%$ less than that of developed countries. The rate of mineral resource conservation is $30 \%$, which is $20 \%$ lower than that of developed countries as well (Liu and Fong, 2010; Yao, 2008).

\subsection{The Definition of SMEs in China}

There is no single definition of SMEs widely accepted in the world. Measurement of SMEs in China is based on employee numbers and annual turnover. According to the standard for Chinese SMEs enacted by the Chinese central government in 2011, the annual turnover of micro-sized enterprises, employing less than twenty workers, is less than three million RMB (about 0.48 million US dollars). The annual turnover of small-sized companies is from three million RMB (about 0.48 million US dollars) to thirty million RMB (about 4.84 million US dollars), where employment is from twenty to 300. Moreover, the annual turnover of medium-sized firms ranges from thirty million RMB (about 4.84 million US dollars) to 300 million RMB (about 48.39 million US dollars), where employment is from 300 to 2000 (The Ministry of Industry of the People's Republic of China, 2012). The standard for Chinese SMEs is more wide-ranging because the number of employees is less than 2000, compared to the United States (less than 500) and the European Union (less than 250). This makes comparison difficult. For this reason, the criterion for SMEs from the American Small Business Administration (SBA), which is also widely accepted in literature on entrepreneurship (European Commission, 2014), has been adopted for this study. Using this definition, the number of employees will be decreased from less than 2000 to less than 500. Indeed, most Chinese SMEs employ less than 500 workers (Wolff and Pett, 2000).

By and large, SMEs have played an increasingly significant role in sustainable economic prosperity, poverty alleviation, and social harmony. For instance, SMEs in China represented $98 \%$ of all types of companies with $85 \%$ of total employment at the end of 2013. Furthermore, Chinese SMEs contributed $61 \%$ of national invest- 
ments, $60 \%$ of overall tax revenues, and approximately $68 \%$ of total export volume. Importantly, more than $75 \%$ of new products as well as $65 \%$ of patented new invention were created by them in 2013 (China Statistical Yearbook, 2013).

Guangdong Province is situated in the south of China near Hong Kong and Macao. Its population was $106,440,000$ at the end of 2014 and it is the most populous province in China. Guangdong Province makes a very significant contribution to national economic growth. For example, the total GDP of Guangdong Province reached 6.779 trillion RMB (about 1.104 trillion US dollars) in 2014, an increased of 7.8\% compared to 2013 and it was ranked number one in China. It was also number one in terms of attracting foreign direct investment (FDI). Additionally, SMEs in Guangdong are very important as a main source of job creation and a key diver of economic development. For example, the number of SMEs in Guangdong Province was 4,386,800 in 2014, which accounted for more than $90 \%$ of total enterprises and provided around $80 \%$ of overall job positions (Guangdong Statistical Yearbook, 2014).

\section{Research Methodology}

\subsection{Research Approach}

A qualitative research method was adopted for this study. Specifically, multiple case studies and semi-structured interviews were viewed as the main research approaches. Because the context of CSR is quite different in different SMEs, multiple case studies were more appropriate than any single one bearing in mind the diverse situations. Additionally, compared with structured-questionnaires and unstructured-interviews, the semi-structured interview, being midway between the extremes of formality and informality, standardization and non-standardization, may be considered an appropriate method for this research topic (Bernard, 2000).

\subsection{Data Resources and Data Collection}

Data collection was divided into three stages. First, SMEs in Guangdong Province were chosen as a research sample. Guangdong Province is one of the important economic centers of China and is famous for its rapid growth of SMEs, successful export-oriented model and FDI reception. The mature and favorable economic environment was conducive for enterprises to implement CSR in advance. Additionally, the principle of data selection followed the concept that the greater the sample differences, the more valid the qualitative analysis results (Strauss and Corbin, 1998). Various SMEs from different industries in Guangzhou City, Shenzhen City, and Zhongshan City were investigated with assistance from the local government and SME associations. This was to avoid research bias as stemming from only a single industry in one city. Last but not least, very successful semi-structured interviews were conducted from June of 2015 to October of 2015. Initially, managers from eighty-six SMEs were contacted by telephone or e-mail to confirm their willingness to be interviewed. Ultimately, twenty managers agreed. The semi-structured interviews were arranged with experienced directors and managers responsible for CSR issues. Each interview took around thirty minutes to make sure the research results were impartial. All interviews were performed in Mandarin, where the recordings were subsequently translated into English by the second author.

It is worth mentioning that archival data and internal information regarding CSR were reviewed as secondary data with company permission. Moreover, media coverage of these SMEs was also considered in this study.

\subsection{Sample Background}

The details of the research sample are shown in Table 2 . It clearly shows that a total of twenty SMEs (with the companies coded from $\mathrm{A}$ to $\mathrm{T}$ ) from different business sectors were investigated in Guangzhou City, Shenzhen City, and Zhongshan City of Guangdong Province. They include eleven private enterprises (PEs) and four state-owned enterprises (SOEs), which constitute the largest representation of this research sample. Furthermore, three foreign-invested enterprises (FIEs) and two collectively-run enterprises (CREs) were covered as well. The number of employees ranged from twenty-seven to 456 in the SMEs. All respondents were leaders directly in charge of CSR issues in their firms (see Table 2). 


\begin{tabular}{|c|c|c|c|c|c|c|c|}
\hline $\begin{array}{l}\text { Company } \\
\text { code }\end{array}$ & Ownership & $\begin{array}{c}\text { Numbers } \\
\text { of Employees }\end{array}$ & $\begin{array}{c}\text { Company } \\
\text { Size }\end{array}$ & Business Field & Market & Interviewee Job Title & Location \\
\hline A & SOE & 456 & Medium & Medical Products & Domestic $100 \%$ & Office Director & Guangzhou \\
\hline B & FIE & 204 & Small & Bag and Pouch & $\begin{array}{l}\text { Domestic } 10 \% \\
\text { International } 90 \% \text {, }\end{array}$ & President & Shenzhen \\
\hline $\mathrm{C}$ & $\mathrm{PE}$ & 198 & Small & Garment & $\begin{array}{l}\text { Domestic 50\% } \\
\text { International 50\% }\end{array}$ & Chairman Secretary & Shenzhen \\
\hline $\mathrm{D}$ & PE & 45 & Small & Toy & $\begin{array}{l}\text { Domestic } 40 \% \\
\text { International } 60 \%\end{array}$ & General Manager & Zhongshan \\
\hline $\mathrm{E}$ & CRE & 108 & Small & Timber Processing & $\begin{array}{l}\text { Domestic } 50 \% \\
\text { International } 50 \%\end{array}$ & Vice-Manager & Guangzhou \\
\hline $\mathrm{F}$ & SOE & 332 & Medium & Petroleum Processing & Domestic $100 \%$ & General Director & Shenzhen \\
\hline G & $\mathrm{PE}$ & 237 & Small & Food Processing & $\begin{array}{l}\text { Domestic } 20 \% \\
\text { International } 80 \%\end{array}$ & Manager of Investment Department & Guangzhou \\
\hline $\mathrm{H}$ & FIE & 151 & Small & Electric Equipment & $\begin{array}{l}\text { Domestic } 30 \% \\
\text { International } 70 \%\end{array}$ & Director of Business Department & Zhongshan \\
\hline I & PE & 62 & Small & Stationary & $\begin{array}{l}\text { Domestic } 50 \% \\
\text { International } 50 \%\end{array}$ & Assistant of General Manager & Zhongshan \\
\hline $\mathrm{J}$ & $\mathrm{PE}$ & 90 & Small & Sport Accessories & Domestic $100 \%$ & Vice-Manager & Guangzhou \\
\hline K & $\mathrm{PE}$ & 373 & Medium & Shoes & $\begin{array}{l}\text { Domestic } 40 \% \\
\text { International } 60 \%\end{array}$ & Director of the Marketing Department & Guangzhou \\
\hline $\mathrm{L}$ & $\mathrm{PE}$ & 179 & Small & Rubber Tire Products & International $100 \%$ & Manager & Guangzhou \\
\hline
\end{tabular}




\begin{tabular}{|c|c|c|c|c|c|c|c|}
\hline M & FIE & 204 & Small & Telecommunication Equipment & \begin{tabular}{|l} 
Domestic $60 \%$ \\
International $40 \%$
\end{tabular} & Vice-Manager & Shenzhen \\
\hline $\mathrm{N}$ & CRE & 83 & Small & Furniture Manufacturing & $\begin{array}{l}\text { Domestic 70\% } \\
\text { International } 30 \%\end{array}$ & Assistant of President & Zhongshan \\
\hline $\mathrm{O}$ & PE & 27 & Small & Crafts & $\begin{array}{l}\text { Domestic 50\% } \\
\text { International } 50 \%\end{array}$ & Assistant of Vice-Manager & Guangzhou \\
\hline$P$ & PE & 59 & Small & Papermaking & $\begin{array}{l}\text { Domestic } 70 \% \\
\text { International } 30 \%\end{array}$ & General Manager & Zhongshan \\
\hline Q & SOE & 248 & Small & Tobacco & Domestic $100 \%$ & Vice-Manager & Zhongshan \\
\hline $\mathrm{R}$ & PE & 86 & Small & Printing & Domestic $100 \%$ & Vice-Manager & Guangzhou \\
\hline $\mathrm{s}$ & PE & 143 & Small & Food Machinery & International $100 \%$ & Office Director & Shenzhen \\
\hline $\mathrm{T}$ & SOE & 231 & Small & Chemistry & Domestic $100 \%$ & Manager & Guangzhou \\
\hline \multicolumn{8}{|c|}{ Source: Summary from twenty SMEs in Guangdong Province. } \\
\hline
\end{tabular}




\section{Findings and Analysis}

\subsection{The Concept and Criteria of CSR}

Table 3 below shows that seventeen SMEs view "concern and responsible for employees" as one of the important aspects of CSR, encompassing $85 \%$ of a total number. For example, Company S (small-sized $\mathrm{PE}$ ) provides good benefits for its employees, such as free food and additional money for festivals as well as a subsidized canteen and accommodations. Company $\mathrm{J}$ (small-sized PE) offers several easy and simple job positions for disabled people. It is worth noting that the majority of companies (Companies A, C, E, F, G, H, J, K, L, $\mathrm{M}, \mathrm{N}, \mathrm{Q}, \mathrm{R}, \mathrm{S}$, and T) provide on-the-job training for employees and seventeen SMEs (Companies A, B, C, E, F, G, H, I, J, $\mathrm{K}, \mathrm{L}, \mathrm{M}, \mathrm{N}, \mathrm{Q}, \mathrm{R}, \mathrm{S}$, and T) mentioned that they never hire children or teenagers under eighteen as employees.

Moreover, products and services of good quality as well as environmental protection and resource saving are the other main aspects of CSR criteria considered by Chinese SMEs, accounting for $75 \%$ and $60 \%$ of the research sample, respectively.

Interestingly, $65 \%$ of SMEs mentioned that how to survive and how to generate more profits are the key issues for them since they are still struggling with the current economic recession. For exam- ple, the general manager of Company D (small-sized PE) said that "as a small business, the concept of CSR is too advanced for us to adopt bearing in mind our current business condition. Now, low price is everything for us instead of concentrating on environmental and social issues." Similarly, the general manager of Company $\mathrm{P}$ (small-sized PE) said that "the most important responsibility of our firm is to make sure there are no payment delays or business downsizing. Unfortunately, CSR would definitely bring high costs. I believe that CSR is still a long way off for our firm."

Moreover, Company I (small-sized $\mathrm{PE}$ ) and Company $\mathrm{O}$ (small-sized $\mathrm{PE}$ ) view "abiding by legal principles" as involving the paying of taxes on time and complying with labor law - CSR in their case. It is noteworthy that only Company A (medium-sized SOE) treats "building an ethical culture and embrace humanitarian principles" as a significant aspect of the CSR concept.

\subsection{Motivation and CSR Practice}

Table 4 below illustrates the reasons why Chinese SMEs implement CSR. The two major drivers behind CSR are the reputation or public images of the company and the requests of global business or international buyers, representing $70 \%$ of all firms,

Table 3. Summary of the Semi-Structured Interview (I)

\begin{tabular}{|l|l|c|c|}
\hline \multicolumn{1}{|c|}{ Description of the CSR domain } & \multicolumn{1}{|c|}{ Company Code } & Total No. of SMEs & Percent \\
\hline Generate profits for shareholders & $\begin{array}{l}\text { B, C, D, F, H, I, J, L, O, } \\
\text { P, Q, R, S }\end{array}$ & 13 & $65 \%$ \\
\hline $\begin{array}{l}\text { Legal principles (e.g., comply with } \\
\text { labor law and tax law) }\end{array}$ & I, O & 2 & $10 \%$ \\
\hline $\begin{array}{l}\text { Concern and responsible for } \\
\text { employees (e.g., job creation, employee } \\
\text { training, employee welfare, and avoid } \\
\text { child labor and labor overtime) }\end{array}$ & $\begin{array}{l}\text { A, B, C, E, F, G, H, I, J, } \\
\text { K, L, N, Q, R, S, T. }\end{array}$ & 17 & $85 \%$ \\
\hline $\begin{array}{l}\text { High product and service quality } \\
\text { Environmental protection and resource } \\
\text { conservation }\end{array}$ & $\begin{array}{l}\text { B, E, E, F, H, K, L, N, P, } \\
\text { Q, R, S, T }\end{array}$ & 12 & $75 \%$ \\
\hline $\begin{array}{l}\text { Build an ethical culture and embrace } \\
\text { humanitarian principles }\end{array}$ & A & 1 & $50 \%$ \\
\hline
\end{tabular}

Source: Summary from twenty SMEs in Guangdong Province. 
Table 4. Summary of the Semi-Structured Interview (II)

\begin{tabular}{|l|l|c|c|}
\hline The Reasons and Motivations behind CSR & \multicolumn{1}{|c|}{ Company Code } & Total No. of SMEs & Percent \\
\hline $\begin{array}{l}\text { Managerial discretion or stockholder } \\
\text { interests }\end{array}$ & A, F, H, T & 4 & $20 \%$ \\
\hline $\begin{array}{l}\text { The reputation of the brand or company } \\
\text { image }\end{array}$ & $\begin{array}{l}\text { A, C, E, F, G, H, K, } \\
\text { L, M, N, P, Q, S, T }\end{array}$ & 14 & $70 \%$ \\
\hline $\begin{array}{l}\text { Requests of global business and } \\
\text { international buyers }\end{array}$ & $\begin{array}{l}\text { B, C, D, E, G, H, I, } \\
\text { K, L, M, N, O, P, S }\end{array}$ & 14 & $70 \%$ \\
\hline $\begin{array}{l}\text { Government requests or legal environment } \\
\text { (mainly tax law and labor law) }\end{array}$ & I, J, O, S, T & 5 & $25 \%$ \\
\hline $\begin{array}{l}\text { The expectations and pressure from the } \\
\text { community, consumers, and competitors }\end{array}$ & K, L & 2 & $10 \%$ \\
\hline
\end{tabular}

Source: Summary from twenty SMEs in Guangdong Province.

respectively. For instance, the chairman secretary of Company C (small-sized PE) said "the well-known brand and a strong reputation will keep the loyalty of existing consumers and attract more new consumers, which is extremely important for the long-term development of our company. Therefore, we prefer to use good fabrics for making high-quality garments in order to establish a good reputation and our own brand. We care and control every processing procedure from raw materials procurement, dress design, and fabric dying to clothes tailoring."

The requirements of global business and international buyers are another key factor pushing Chinese SMEs to adopt CSR. For example, the president of Company B (small-sized FIE) mentioned that "as one of Philips' suppliers, we must strictly follow business ethics such as protection of employee rights and resource conservation, which are requested by Philips headquarters. Philips examines the supplier audit every four years. If we fail it, we will definitely lose supplier qualification which will lead to very significant damage to our business." Similarly, the manager of the investment department of Company $\mathrm{G}$ (small-sized PE) said, "our enterprise is one of the food processors for a Canadian fishing company. I clearly remembered that in early 2002 our Canadian customer asked for the factory inspection reports, including food safety, employee rights, sanitary environment, etc. Honestly, we had a very tough period when we found out what CSR is the first time. After more than ten years of groping in the international markets, we have learned a lot from our global partners. And now, we are able to detect our problems ourselves in advance." Furthermore, certifications of the International Standard Organization - ISO 9000 and ISO 14000 are deemed to be licenses for entry to overseas markets for many SMEs. The manager of Company L (small-sized PE) said, "at first, we felt it was very difficult to enter American markets. However, since our four production lines passed the U.S. Standard in 2005, our export volumes of rubber tire products have dramatically increased. Certification is like a passport for us and all the efforts we made are worth it now."

However, the vice-manager of Company J (small-sized PE) mentioned that "we admitted the importance of international certifications. However, due to rising labor costs and raw material prices, our company is even suffering on domestic markets. We lack sufficient working capital, time, and highly-qualified employees needed to apply for international certification." "Our company usually exports products to developing countries in Africa, the Middle East, and Southeast Asia. However, the trade requirements and standards of the European Union and North America are very strict and complicated for us. Our business is small with low profit margins so we cannot afford to prepare the international certification or take any risks to get them," said the assistant of the vice-manager of Company O (small-sized PE). 
Additionally, "government requests or legal environment" as well as "managerial discretion or stockholder interests" were the other two reasons for CSR implementation, accounting for $25 \%$ and $20 \%$ of all SMEs, respectively. For example, the director of the business department of Company H (small-sized FIE) said, "based on the new labor law issued in 2013, if we terminate unexpired labor contracts, our enterprise must compensate those employees with at least three-month salaries. Therefore, we have to abide by the labor law and contracts seriously." "Although our export business is severely affected by the economic crisis and depression, we still pay tax on time and comply with labor law," mentioned the assistant of the general manager of Company I (small-sized PE) and the assistant of the vice-manager of Company O (small-sized PE).

On the other hand, the vice-manager of Company $\mathrm{J}$ (small-sized PE) admitted that "the local government provides tax preferences for enterprises offering job positions for disabled people, which was the primary motivation for us to hire them." However, the manager of Company $\mathrm{T}$ (small-sized SOE) complained that "the current legal and regulatory environment is still imperfect and it is very difficult to adopt CSR principles. For instance, our company has put lots of time and money into upgrading environmental equipment and still, we have to pay a lot of extra fees for bidding and approval procedures. We cannot even get any tax incentives for these sustainable investments."

Furthermore, the role of "managerial discretion or stockholder interests" is also crucial for CSR practices. For example, the office director of Company A (medium-sized SOE) said, "the most important factor behind CSR in our company is our leaders' interest and their decisions. Our executive manager decided to donate $0.1 \mathrm{RMB}$ (around 0.016
US dollar) to Project Hope for each box of medicine sold since 2004. Apart from this, the executive manager established a charity funds to improve primary education in the western regions of China." "With respect to CSR implementation, it is very necessary to acquire the support of the leaders. Our bosses agreed to invest in new environmentally-friendly facilities in order to save more energy and resources," according to the general director of Company F (medium-sized SOE).

Moreover, only Company K (medium-sized PE) and Company L (small-sized $\mathrm{PE}$ ) considered "the expectation and pressure of communities, consumers, and competitors" as one of the reasons for their CSR adoption. Both companies agreed that intense market competition forces them to focus more on high-quality and environmentally-friendly products. However, they did not mention any expectations or pressures from communities.

\subsection{CSR Outcomes}

Table 5 below reveals the outcomes of CSR from the twenty SMEs. A total of $55 \%$ of the SMEs present positive outcomes resulting from their CSR practices. For example, because of its high quality products and strong reputation, Company C (small-sized PE) attracts more new consumers. Good social performance helps to establish a favorable corporate image such as in the case of Company A (medium-sized SOE) and Company F (medium-sized SOE). Additionally, concern and a sense of responsibility for employees are beneficial to maintain their long-term retention as in the case of Company S (small-sized PE).

However, there are eight enterprises that had negative outcomes from CSR. This represents forty percent of all SMEs. Specifically, the majority of them believe CSR places unnecessary financial burdens on their businesses, especially regarding the

Table 5. Summary of the Semi-Structured Interview (III)

\begin{tabular}{|l|l|c|c|}
\hline \multicolumn{1}{|c|}{ CSR Outcomes } & \multicolumn{1}{c|}{ Company Code } & Total No. of SMEs & Percent \\
\hline Positive Outcomes & A, B, C, F, G, H, J, K, L, M, S & 11 & $55 \%$ \\
\hline Negative Outcomes & D, E, I, N, O, P, R, T & 8 & $40 \%$ \\
\hline Unknown Outcomes & Q & 1 & $5 \%$ \\
\hline
\end{tabular}

Source: Summary from twenty SMEs in Guangdong Province. 
protection of environment and employee rights. Compared to large companies, these participates declare that SMEs lack adequate capital and available resources and so cannot afford the greater costs of CSR implementation. Worse still, a large number of SMEs in China have struggled for their very survival since the economic crisis broke out in 2008. Environmentally-friendly manufacturing procedures are seen as ancillary activities and with the humanitarian behavior aggravate monetary strain. Many firms believe this could damage their financial situation, including Company $\mathrm{P}$ (small-sized PE), Company O (small-sized PE), Company E (small-sized CRE), Company R (small-sized PE), and Company N (small-sized CRE). Furthermore, some SMEs assert that most customers are still seeking cheap price and CSR does not attract their attention or interest. It is also very difficult for companies to tell consumers what kind of CSR they have adopted, such as in the case of Company D (small-sized PE), Company I (small-sized $\mathrm{PE}$ ), and Company $\mathrm{O}$ (small-sized PE).

Additionally, the vice manager of Company Q (small-sized SOE) mentioned that "I need the real statics to believe CSR generates tangible profits for us rather than just empty talk. Now, we cannot spend too much money and time on examining the inputs and outputs of all our investments on environmental protection and energy conservation. Therefore, I am not sure whether the CSR implementation of our firm brings any good outcome or not."

\section{Discussions and Recommendations}

As discussed above, the criteria, motivations, practices, and outcomes of CSR for SMEs in China were explained. Taken all together, several constraints in the adoption CSR by Chinese SMEs can be summarized. On the basis of the discovered barriers, appropriate recommendations will be provided accordingly.

\subsection{The Challenges of CSR Implementation}

\subsubsection{Imperfect Legal Environment and Incomplete Normative System}

Although the Chinese economic reform has borne fruit as of 1978, the legal and normative systems are still incomplete and cannot keep up with the fast economic development (Xu and Yang, 2010). In the research sample, Company I (small-sized $\mathrm{PE}$ ) and Company $\mathrm{O}$ (small-sized PE) regard "abiding by legal principles" as paying taxes on time and complying with labor law - their CSR practice. This clearly indicates that CSR adoption by Chinese SMEs is being carried out in an unfavorable environment. The legal system is imperfect. It lacks adequate protection of legal interests, which leads to tax evasion and an unclear demarcation of property rights (e.g., counterfeit and imitative production). Therefore, the incomplete legal and normative systems exert harmful influence on the protection of SME legal rights. Consequently, this hampers their CSR practice as well.

\subsubsection{Weak CSR Awareness and Motivation}

Research has found that several leaders (from Company A, Company F, Company $\mathrm{H}$, and Company $\mathrm{T}$ ) do have a relatively strong awareness and motivation with respect to CSR. However, this accounts for only $20 \%$ of the research sample and implies that a lot of Chinese SMEs, with limited understanding of CSR, have followed easy-win business strategies and pursued short-term commercial gains.

Furthermore, some interviewees insisted that the majority of Chinese consumers still care mostly about cheap products, not CSR. Even worse, there are $25 \%$ of all SMEs (Company P, Company O, Company E, Company R, and Company N) actually treating CSR as a financial burden and unnecessary.

\subsubsection{Inadequate Capital Resources and Financial Support}

The interviewees from Company D (small-sized PE), Company P (small-sized $\mathrm{PE}$ ), Company J (small-sized PE), and Company O (small-sized PE) mentioned the prime problem facing their business is a shortage of capital resources and financial support. They regard this as their biggest challenge in adopting CSR principles.

\subsection{CSR Practice Recommendations}

\subsubsection{Intensifying the Building of the Legal System}

The Chinese central and local governments play a key role in the promotion of CSR. The Chinese central government must continue efforts aimed at building 
a legislative system as well as restructuring the marketing order. This is especially true in the case of regulation enforcement. Moreover, as a response to the establishment of a harmonious society and the development of green GDP, encouraged by the central government (Wang and Juslin, 2011; Noronha et al., 2013), Chinese local government should provide tax incentives as well as minimize political interferences regarding the sustainable investments of SMEs.

\subsubsection{Enhancing CSR Awareness and Motivation}

In the case of Chinese SMEs, reducing implicit costs by way of irresponsible and unethical behavior, such as wage-cutting or unsustainable production, would lose them the loyalty of their employees and result in more spending on explicit expenditures. For example, enterprises in China have to take on the additional costs of export certifications - between one million RMB (around 0.16 million US dollars) and two million RMB (around 0.32 million US dollars) -in order to follow regulations concerning the registration, evaluation, authorization, and restriction of chemicals (REACH) in the European Union. This is intended so as to safeguard the better protection of human health and the natural environment introduced by the European Union in June of 2007 (Liu and Fong, 2010). However, if the appropriate actions regarding human health and environmental protection are taken by Chinese export-oriented SMEs, the savings involved would mitigate their financial pressure. Furthermore, according to a quantitative study of 100 electronic firms in Malaysia, by investing in CSR an enterprise can achieve a positive outcome with regard to its financial performance (Raman et al., 2012). Hence, CSR could create an additional competitive advantage for SMEs instead of financial burdens and needless practices.

Moreover, based on previous investigations of consumer behavior, approximately $90 \%$ of customers would stop purchasing a product if they knew of any illegal and immoral practice on the part of the manufacturer. At the same time, customers are more willing to buy a product with social or environmental benefits, even at slightly higher prices (Nik Ramli et al., 2013; Rahman and Post, 2012; Carroll, 1991; Sen et al., 2006; Cochran, 2007). This implies that most consumers prefer to pay for high-quality and green products. Therefore, it is necessary to strengthen awareness and emphasize the importance of CSR in SMEs in China.

Additionally, because CSR is seen as a significant shaper of corporate image, SMEs should take advantages of various marketing tools to voice their CSR concerns and implementation. For example, the CSR initiatives and activities of SMEs could be made known to the public through e-mail marketing, social media, and public relations.

\subsubsection{Changing Business Strategy and Providing Diversified Capital Resources}

By and large, Chinese SMEs are heavily dependent on a low-pricing strategy. This has been regarded as their main competitive edge. However, it is well-known that a low-pricing strategy with narrow profit margin cannot achieve sustainable competitiveness (Cunningham and Rowley, 2008). To attract more profits, SMEs in China should transform their low-pricing strategy and traditional resource-intensive manufacturing model into more competitive and sustainable approaches, including an innovation-oriented strategy or marketing/products niche strategy (Kanamori et al., 2007).

There are more measures that should be undertaken in order to solve SME financial problems, including the providing of various forms of financial support. The central and local governments should provide tax deduction or exemption as an incentive mechanism for CSR implemented by Chinese SMEs. Banks should offer low-interest loans to SMEs so as to encourage their CSR initiatives. Furthermore, special funds should be established by commercial institutions in order to expand the financial channels of SMEs in China.

\section{Conclusion}

This study evaluates CSR implementation by SMEs in China on the basis of criteria such as motivation, practice, and outcome. Twenty SMEs from different industries in Guangdong Province made up the research sample. Analysis of research results identified three major challenges to CSR implementation by Chinese SMEs 
- the incomplete legal and normative systems, weak CSR awareness and motivations, and the inadequate capital resources and financial support. Accordingly, three recommendations for the Chinese government and the SMEs themselves are also provided. Most importantly, the entrepreneurs of the SMEs have to keep in mind that the efforts of CSR do not automatically and instantly translate into large profits. However, SMEs that are consistently more socially responsible in their business practices can achieve sustainable development through increased customer loyalty and employee commitment as well as a strong corporate reputation and image.

Owing to limited time and resources, merely twenty SMEs from one province were encompassed by this study. Moreover, only one research method, the semi-structured interview, was adopted. These constraints can be deemed to restrict the research scope and the influence of research findings. Therefore, any future research should increase data collection through multiple study approaches in order to gain more valuable knowledge.

\section{Notes}

Pursuant to confidentiality policy, the authors are not allowed to disclose the names involved in the research sample.

\section{References}

Andreasen, A.R. (1994). Social Marketing: Its Definition and Domain. Journal of Public Policy and Marketing, 13, 108-114.

Bernard, R. (2000). Social Research Methods: Qualitative and Quantitative Approaches. Thousand Oaks: Sage.

China Statistical Yearbook. (2013). National Bureau of Statistics of China, Beijing: China Statistics Press. Retrieved from: http://www.stats.gov.cn/ tjsj/ndsj/2013/indexch.htm. (November 22, 2014).

Cochran, P.L. (2007). The Evolution of Corporate Social Responsibility. Business Horizons, 50(6), 449-454.

Chattananon, A., Lawley, M., Supparerkchaisakul, N. and Leelayouthayothin, L. (2008). Impacts of a Thai Cause-Related Marketing Program on Corporate Image. International Journal of Emerging Markets, 3(4), 348-363.

Chan, A. (2005). China Says No to Developed Countries' Corporate Social Responsibility. Retrieved from: http://www.afgventuregroup.com/asian_anal-
ysis/China- $\% 20$ China $\% 20$ Says $\% 20$ No $\% 20$ To $\% 20$ Developed $\% 20$ Countries $\% 20$ Corporate $\% 20$ Social\%20Responsibility.php. (21.03.2015).

China Council for International Cooperation on Environment and Sustainable Development. (2013). Policy Recommendations on Financial Mechanisms for Environmental Protection in China. Journal of Business Management, 39(4), 2031-3867.

Carroll, A.B. (1999). Corporate Social Responsibility: Evolution of a Definitional Construct. Business and Society, 38(3), 268-295.

Carroll, A.B. (1991). The Pyramid of Corporate Social Responsibility: Toward the Moral Management of Organizational Stakeholders. Business Horizons, 30(4), 39-48.

Chen, J., Huang, Q., Peng, H. and Zhong, H. (2015). Research Report on Corporate Social Responsibility of China. China: Social Sciences Academic Press.

Cunningham, X.L. and Rowley, C. (2008). The Development of Chinese Small and Medium Enterprises and Human Resource Management: A Review. Asia Pacific Journal of Human Resource, 46(3), 353-379.

Daub, C.H. and Ergenzinger, R. (2005). Enabling Sustainable Management Through a New Multi-Disciplinary Concept of Customer Satisfaction. European Journal of Marketing, 39(9), 998-1012.

Dolan, P. (2002). The Sustainability of Sustainable Consumption. Journal of Macro Marketing, 22, 170-181.

European Commission (2001). Promoting a European Framework for Corporate Social Responsibility. Green Paper: Employment and Social Affair. Belgium: The European Commission.

European Commission (2014). Annual Report on European SMEs 2013/2014 - A Partial and Fragile Recovery. Retrieved from: http://ec.europa.eu/ small-business/index_en.htm. (10.04.2015).

Fedrigo, D. and Hontelez, J. (2010). Sustainable Consumption and Production: An Agenda beyond Sustainable Consumer Procurement. Journal of Industrial Ecology, 10-12.

Gupta, S. and Pirsch, J. (2006). The Company-Cause-Customer Fit Decision in Cause-Related Marketing. Journal of Consumer Marketing, 23(6), 314-326.

Guangdong Statistical Yearbook (2014). The Bureau of Statistics in Guangdong Province, Guangzhou: The Statistics Press of Guangdong Province.

Kanamori T., Lim, J.J. and Yang, T. (2007). China's SMEs Development Strategies in the Context of a National Innovation System. Asian Development Bank Institute (ADBI) Discussion Paper No. 55. Retrieved from: http://s3.amazonaws.com/ academia.edu.documents/30900063/id6.pdf?AW SAccessKeyId =AKIAJ56TQJRTWSMTNPEA\& 
Expires $=1447184393 \&$ Signature $=$ MTnfgt $\% 2 B p$ 3Pos4j1xEzmEg3kcvmA\%3D\&response-contentdisposition $=$ inline $\% 3 \mathrm{~B} \% 20$ filename $\% 3 \mathrm{DChinas}$ SME_development_strategies_in_the.pdf. (02.12.2014).

Korschun, D., Bhattacharya, C.B. and Swain, S.D. (2014). Corporate Social Responsibility, Customer Orientation, and The Job Performance of Frontline Employees. Journal of Marketing, 78, 20-37.

Kolk, A., Hong, P. and Dolen, van W. (2010). Corporate Social Responsibility in China: An Analysis of Domestic and Foreign Retailers' Sustainability Dimensions. Business Strategy and the Environment, 19(1), 289-303.

Li, Q., Luo, W., Wang, Y.P. and Wu. L.S. (2013) Firm Performance, Corporate Ownership, and Corporate Social Responsibility Disclosure in China. Business Ethics: A European Review, 22(2), 159-173.

Luetkenhorst, W. (2003). Corporate Social Responsibility and the Development Agenda: Should SMEs Care? Working Paper No.13. Vienna: United Nations Industrial Development Organization.

Li, X.C. (2012). SMEs in Selected Countries in East Asia. Cass Business School, City University, London.

Liu, H.X. and Fong, M. (2010). The Corporate Social Responsibility Orientation of Chinese Smal and Medium Enterprises. Journal of Business Systems, Governance and Ethics, 5(3), 33-50.

Lee, Y.K., Kim, Y.S., Lee, K.H. and Li, D.X (2011). The Impact of CSR on Relationship Quality and Relationship Outcomes: A Perspective of Service Employees. International Journal of Hospitality Management, 31, 745-756.

Maignan, I. and Mcalister, D.T. (2003). Socially Responsible Organizational Buying: How Can Stakeholders Dictate Purchasing Policies. Journal of Macro Marketing, 23, 78-89.

McWilliams, A., Siegel, D.S. and Wright, P.M (2006). Corporate Social Responsibility: Strategic Implications. Journal of Management Studies, 43(1), 246-268.

Maignan, I. and Ferrell, O. C. (2004). Corporate Social Responsibility and Marketing: An Integrative Framework. Journal of the Academy of Market ing Science, 32(1), 3-19.

Mankelow, G. (2008). Social Responsibility Paradox of Small Business Human Resource Management Practices. The International Journal of Human Resource Management, 19(12), 2171-2181.

Noronha, C., Tou, S., Cynthia, M.I., and Guan, J.J. (2013). Corporate Social Responsibility Reporting in China: An Overview and Comparison with Major Trends. Corporate Social Responsibility and Environmental Management, 20, 29-42.
Nik Ramli, N.A.R., Nor Irwani A.R. and Shaiful A.K. (2013). Environmental Corporate Social Responsibility as A Strategic Marketing Initiatives. Procedia: Social and Behavioral Sciences, 130, 499-508.

Nik Ramli, N.A.R. and Nor Irwani, A.R. (2013). CSR Practices and Customer Loyalty: The Mediat ing Role of Corporate Image. International Conference on Administrative Science and Technology, Malaysia.

Oberseder, M., Schlegelmilch, B.B. and Gruber, V. (2011). Why Don't Consumers Care about CSR: A Qualitative Study Exploring the Role of CSR in Consumption Decisions. Journal of Business Ethics, $104,449-460$

Orlitzky, M., Schmidt, F. and Rynes, S. (2003). Corporate Social and Financial Performance: A Met Analysis. Organization Studies, 24(3), 403-441.

Polonsky, M.J. and Wood, G. (2001). Can the Over Commercialization of Cause-Related Marketing Harm Society? Journal of Macro Marketing, 21(8), 8-22.

Pakseresht, A. (2010). Brand Equity and Corporate Responsibility: A Review of Brand Valuation Methods. Retrieved from: http://www.essays.se/ essay/9e20739689/ (18.04.2015).

Raman, M., Lim, W. and Nair, S. (2012). The Impact of Corporate Social Responsibility on Consumer Loyalty. Journal of Kajian Malaysia, 30(2), 71-93.

Rahman, N. and Post, C. (2012). Measurement Issues in Environmental Corporate Social Responsibility (ECSR): Toward a Transparent, Reliable and Construct Valid Instrument. Journal of Business Ethic, 105, 307-319.

Strauss, A.L. and Corbin, J.M. (1998). Basics of Qualitative Research: Techniques and Procedures for Developing Grounded Theory, Second Edition, Thousand Oaks, California: SAGE.

Sen, S., Bhattacharya, C.B. and Korschun, D. (2006). The Role of Corporate Social Responsibility in Strengthening Multiple Stakeholder Relationships: A Field Experiment. Journal of the Academy of Marketing Science, 34(2), 158-166.

Saunders, R. (2006). CSR: How to Get an Ethical Advantage. Retrieved from: http://www.highbeam. com/doc/1G1-156029766.html. (March 11, 2015).

The Ministry of Industry of the People's Republic of China. (2012). Notice of the Issuance of the SME Program Standards Require. Retrieved from: http:// wenku.baidu.com/view/26300f6fa45177232f60a224. html. (June 13, 2014).

Vaaland, T.I., Heide, M. and Grønhaug, K. (2008). Corporate Social Responsibility: Investigating Theory and Research in the Marketing Context. European Journal of Marketing, 42(9), 927-953. 
Welford, R. (2005). Corporate Social Responsibility in Europe, North America and Asia. Journal of Corporate Citizenship 17, 33-52.

Wang, L. and Juslin H. (2011). The Effects of Value on the Perception of Corporate Social Responsibility Implementation: A Study of Chinese Youths. Corporate Social Responsibility and Environmental Management, 18, 246-262.

Wolff, A. J. and Pett, T. L. (2000). Internationalization of Small Firms: An Examination of Export Competitive Patterns, Firm Size, and Export Performance. Journal of Small Business Management, 38(2), 34-47.

Whipp, L. and Anderlini, J. (2010). Chinese Economy Eclipses Japan's. Financial Times, August 16. Retrieved from: http://www.ft.com/ cms/s/0/935ac446-a8d7-11df-86dd-00144feabdc0. html\#axzz3r6TAFNMA. (02.05.2015).

Whetten, D.A., Rands, G.P. and Godfrey, P (2002). What Are the Responsibilities of Business to Society? In: A.M. Pettigrew, H. Thomas and
R. Whittington (eds.), Handbook of Strategy and Management. London: Sage.

Xun, J.Y. (2013). Corporate Social Responsibility in China: A Preferential Stakeholder Model and Effects. Business Strategy and the Environment, 22, 471-483.

$\mathrm{Xu}, \mathrm{S}$. and Yang, R. (2010). Indigenous Characteristics of Chinese Corporate Social Responsibility Conceptual Paradigm. Journal of Business Ethics, 93(6), 321-333.

Yin, J.L., and Zhang, Y.L. (2012). Institutional Dynamics and Corporate Social Responsibility (CSR) in an Emerging Country Context: Evidence from China. Journal of Business Ethics, 111, 301-316. Yao, Y.L. (2008). The Suggestion to Strengthen the Social Responsibility of SMEs. Journal of SMES Development, 7(2), 123-124.

$\mathrm{Zu}$, L., and Song, L. (2009). Determinants of Managerial Values on Corporate Social Responsibility: Evidence from China. Journal of Business Ethics, 88(2), 105-117. 